\title{
A Mobile and Web Application for Mapping Disaster Volunteers' Position in Indonesia
}

\author{
https://doi.org/10.3991/ijim.v11i3.6477 \\ Theresia Devi Indriasari \\ Universitas Atma Jaya Yogyakarta, Yogyakarta, Indonesia \\ devestaff.uajy.ac.id \\ Kusworo Anindito \\ Universitas Atma Jaya Yogyakarta, Yogyakarta, Indonesia \\ kusworo@staff.uajy.ac.id \\ Eddy Julianto \\ Universitas Atma Jaya Yogyakarta, Yogyakarta, Indonesia \\ eddiedb@staff.uajy.ac.id \\ Bertha Pangaribuan \\ Universitas Atma Jaya Yogyakarta, Yogyakarta, Indonesia \\ blppbertha@gmail.com
}

\begin{abstract}
Indonesia is a country located on top of some tectonic plates that bring potential natural disasters. Disaster management system is considered essential in controlling the situation in the site both before and after the disaster takes place. In disaster situation, the government and society are involved in a volunteer team in order to help minimize victims and support survivors. However, the volunteering activities are often hindered since there are problems in the disaster site. One of the problems is late responses due to poor coordination among volunteers that drives the delay in disaster relief. Therefore, it is necessary to have an application that maps the positions of volunteers in a disaster site, so that the disaster management coordinator can disseminate volunteers to disaster areas based on needs. The purpose of the study is to propose an application called 'MyMapVolunteers' that effectively and efficiently detects the position of the volunteers in order to improve disaster management service. In this case, real time and location based service technology will able to detect the position of each volunteer. 'MyMapVolunteers' is composed of two platforms, which are mobile and web applications. Mobile platform is an application that uses GPS function provided by the smartphone to find the volunteers' location coordinates and then send the data of the location automatically and manually. The web platform is used to receive volunteers' location data and to present them in google map, therefore disaster management coordinator can monitor the positions of and search for volunteers faster.
\end{abstract}

Keywords - disaster management, location based service, smartphone, volunteers. 


\section{Introduction}

Indonesia has a large range of natural resources. However, it also faces a lot of potential natural disasters [1] since geographically it is an archipelago which is located above the intersections of the Tectonic Plates of Eurasia, Indo-Australia, Philippines, and Pacific. In the southern and eastern of Indonesia there is a volcanic arc ranging from Sumatera, Java, Nusa Tenggara, and Celebes which edge is composed of old volcanoes and valleys, dominated by swamps. This condition potentially brings various natural disasters such as volcano eruptions, earthquakes, tsunamis, and landslides [2]. Figure 1 depicts the intensity of natural disasters in Indonesia within the last decade [3].

According to Indonesian Act number 24 year 2007 [4] a disaster is defined as "an event or a series of events that threatens and disturbs life and the living of the society as a result of either a natural, non-natural or human factor that causes casualties, nature damage, financial loss and psychological impacts." When a disaster takes place, an emergency quick response is essential to deal with the negative impacts that cover searching, rescuing and evacuating victims and properties, meeting basic needs, providing shelters, managing refugees, rescuing, and revitalizing structures and infrastructures [5].

Disaster management is the responsibility of the central and local government. The principles in disaster management are fast and target oriented, priority, coordination and coherence, and effective and efficient. The main purpose of the disaster management is to save the society from the threats of a disaster and to ensure that the mitiga-

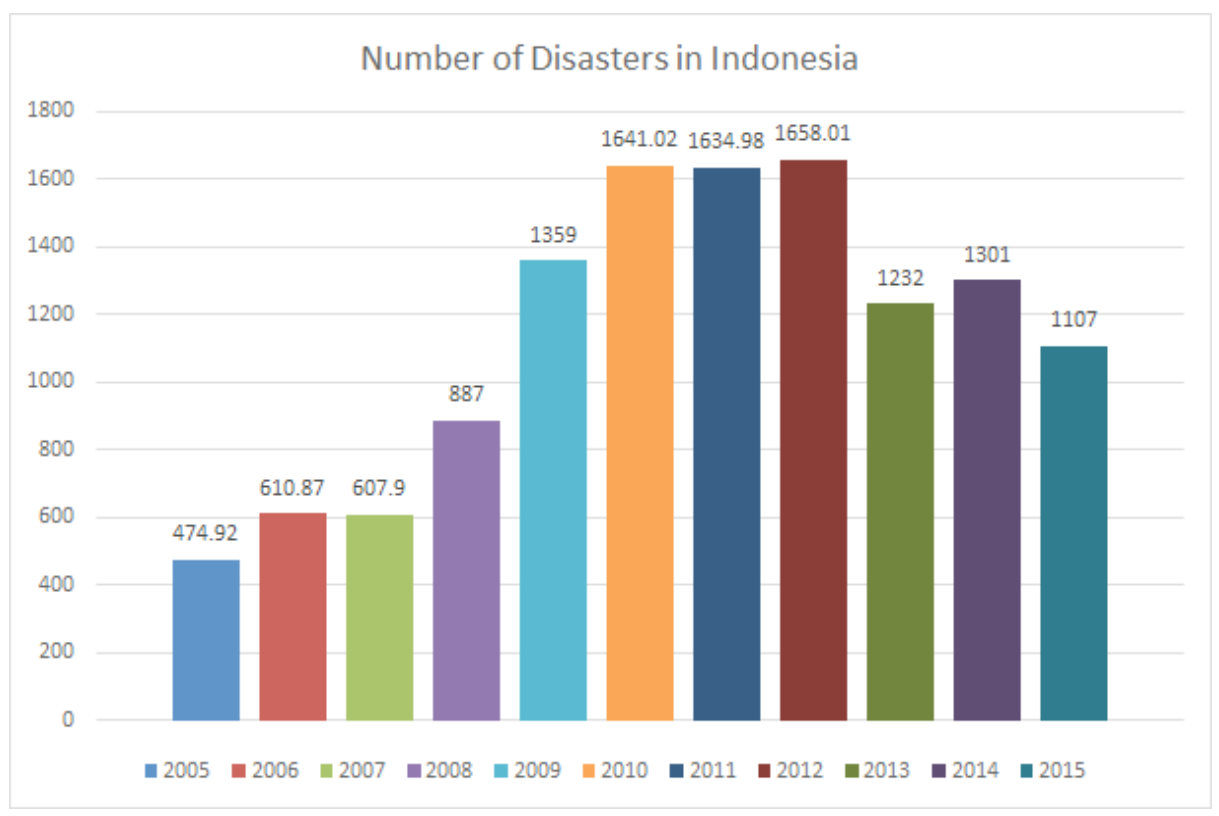

Fig. 1. Number of Disaster in Indonesia (2005-2015) [3] 
tion will run smoothly as planned in one unity, well-coordinated and thorough [4]. The organizer runs the disaster management based on the Indonesian Act Number 24 Year 2007 is Badan Nasional Penanggulangan Bencana (BNPB-National Bureau of Disaster Mitigation) by involving the society and stake holders, especially the business community, in the efforts of mitigating a disaster. The action needs integration of all the elements to create a strong optimum force towards a society that can be tough in facing a disaster. It is necessary to understand that the one responsible for the disaster is not only the government. The business world and the society, as well as universities, are also responsible to participate actively [6].

The society can take part in the disaster management by becoming volunteers. The presence of volunteers is an effective solution to the lack of human resources in disaster mitigation especially in the government organization like BPBD (National Bureau of Disaster Mitigation). They are a group of people with skills and interests to work as volunteers to mitigate the disaster effects. It does not matter how big is the human resources; it will never suffice to administer the disaster management. However, small human resources supported by sufficient infra and supra structures will be adequate such as in legislation, planning, financing, and science mastery and technology application; they become one strong united force for disaster mitigation [6]. The task as a volunteer is full of challenges since what happens in the disaster site most of the time is unpredictable. Two volunteers from "Taruna Siaga Bencana Yogyakarta" experienced a disaster when they were joining the 2010 Merapi eruption SAR (Search and Rescue) team. The two were trapped and died in a site when pyroclastic flow hit their shelter. Other volunteers heard the news and tried to help but they were too late to reach the site [7].

The case shows that accurate, fast and correct information in an emergency situation can minimize the losses. This situation shows the importance of communication between volunteers and authority in controlling the disaster management. Besides the fact that volunteers are not spread out evenly, the situation may also put volunteers in danger. Therefore, an application, that uses location based service technology, that can map the volunteer position in real time is necessary to keep them safe. What has happened so far is that the system used to monitor the volunteer deployment in the disaster site is by using the phone call, by calling each volunteer one by one. In an emergency situation, detecting the location with phone calls will result in location ambiguity. In an emergency situation people sometimes experience disorientation so they might make mistakes in determining their locations [8]. Therefore, a reliable direction that can detect the right location fast is necessary. The location data should cover longitude and latitude that can be periodically updated with the use of smartphone devices used by the volunteers. The operator can get the data by activating GPS service that usually is built in a smartphone.

This research proposes 'MyMapVolunteers', a mobile and web application. The application is composed of two parts: mobile and web applications. The mobile application which is installed in smartphones carried by the volunteers will send their positions periodically to the server. While the web platform is essential to receive location data and present the results to the operator in a google map, so that the disaster man- 
agement coordinators can monitor, manage the deployment of the volunteers and search for the volunteers the fastest as possible.

\section{Volunteers In Disaster Management}

The definition of volunteer usually involves two concepts, giving a service to others willingly and giving service to other parties without getting financial compensation [9]. Volunteering refers to "any activity in which time is given freely to benefit another person, group or organization" [10]. According to Whittaker et al. [11] activities done by volunteers are optional since there is no contract, family relation, or friendship between the helpers and the ones being helped, organized activities which are done to help other people, society or organization without payment. Shaskolsky [12] defined volunteerism as "any act that is oriented to the director indirect service of some other person or thing regardless of whether or not such act serves the selfinterest of the actor". Wolensky regards volunteerism as 'any monetarily uncompensated, willful action, be it spontaneous or organised, oriented toward the protection and/or restoration of symbols, interests, people, or other high priority values of a personal or group nature' [13]. “A volunteer is any individual accepted to perform services by the lead agency (which has authority to accept volunteer services) when the individual performs services without promise, expectation, or receipt of compensation for services performed" [14].

There are three types of volunteers according to Fernandez, et al.: 1) Volunteers on an assigned resource: the special task given by incident command system, such as a member of SAR team; 2) Recruited Volunteers: has special skills implemented in the disaster site and asked to help the incident command system, such as the owner or operator of heavy tools needed by the SAR team; and 3) Spontaneous volunteers: no specially recruited and willingly help without payment, such as the owners of food stall that donate free food for the survivors [9]. This paper refers to volunteers on an assigned resource and recruited volunteers.

The Panca Dharma of Disaster Management Volunteers states that independence, professionalism, solidarity, accountability, skill exercise, skills and abilities of the volunteers are needed so that they can become professional volunteers in carrying out the humanity tasks [15]. Some skills or special abilities that the volunteers need to have, among others, are: planning, fast thinking, education, mapping, SAR, evacuation, logistic transportation, open kitchen, health, shelter, temporary settlement, sanitation, psychology, etc. [6]. Based on the skill or abilities needed, volunteer mapping application takes the volunteers' skills and abilities listed in the database into consideration.

Based on the Decree of the Head of The National Bureau of Disaster Mitigation Number 7 Year 2011 on the manual for volunteers in disaster management [15], the roles of volunteers based on the time is divided into three: when there is no disaster, in the disaster emergency, and post-disaster or the aftermath. When there is no disaster, volunteers work to minimize disaster risks or mitigation and training. The training covers basic and advanced training on emergency disaster technical management, 
rehearsals, and disaster simulation. In the emergency situation the roles of volunteers cover searching, rescuing and evacuating the people in the affected areas, saving the potential victims by giving them priority service. In the post-disaster or the aftermath, volunteers help in the collecting and processing data on the losses either in the form of destruction in housing and infrastructure, social, economy. Volunteers can also take parts in rehabilitating actions both physically and non-physically in the early recovery period.

There are two types of risks caused by ineffective task distribution among volunteers and lack of volunteer coordination. The first is that the failure to make use of volunteers can create "mortality of disaster victims, damage to property, reduced ability to cope for volunteers, poor public perception of emergency responders" [9]. The second, the risks caused by unskilled or uncoordinated volunteers are "disruption of organized response (decreased response effectiveness, decreased/limited resources available to victims), morbidity/mortality of volunteers, disaster victims, and emergency responders" [9].

\section{Disaster Management Issue In Indonesia}

Purnomo \& Sugianto [16] state that $87 \%$ of Indonesia is prone to natural disaster that cost in financial loss and the life of the people. Therefore, disaster management needs more attention and improvement from the government. The situation encourages the government and officials to carry out a disaster management activities by founding National Bureau of Disaster Management-Badan Nasional Penanggulangan Bencana (BNPB) that has a branch in every province called Local Bureau of Disaster Management-Badan Penanggulangan Bencana Daerah (BPBD). This organization copes with natural disaster such as earthquake, flood, volcano eruption, landslide, and even tsunami. According to Act Number 24 Year 2007, one of the BNPB tasks is to coordinate the integration and plan of disaster management thoroughly. Therefore, it is necessary to provide accurate and effective data. However, the problem that often happens in emergency activities is coordinating the volunteers. Some times volunteers congregate in one location so that the mitigation cannot run smoothly and thoroughly since there is a lack of accurate information on the volunteers location. It is possible that one volunteer finds many victims but he cannot communicate with other volunteers to evacuate the victims. This is a distressing situation since it will result in higher number of casualties. It show that what BPBD needs is not merely to coordinate volunteers, but also to enable the coordination among volunteers in emergency situation when dealing with disaster.

The mapping of the volunteers in the disaster site in an emergency situation by calling them one by one is not an easy thing to do since there are so many activities to carry out. Therefore, an integrated periodical search for volunteers can solve the problem. Since there is no official system set by the government to support the activity, it is necessary to provide complete structure and infrastructure that support the process of supervising and searching for volunteers when a disaster takes place. 


\section{The Use Of Smartphone In Disaster Situation}

Mobile phone is one of information and communication technology (ICT) which is quite popular to send messages. Recently mobile phone has switched to smartphone [17][18]. Smartphone is a medium to replace radio and television to communicate, to send information faster to more people so it reduces time and cost [19][20]. Smartphone technology plays a more important role in quick response emergency situation as it can trace down emergency zone; with the GPS built-in it can send and receive relevant data updates with the use of internet connection (mobile data) [21]. The following is the explanation of how smartphone can function effectively in disaster or emergency handling.

Fajardo and Oppus developed Disaster Droid application [22]. The application calculates the best route to reach different geographic locations. The route helps volunteers to reach the maximum number in one disaster site within the best time. Disaster Droid application is an implementation of Travelling Salesman Problem (TSP) and uses genetic algorithm to provide solution. In this application the geographical area is illustrated as longitude and latitude. Basically, Disaster Droid shows two presentations. One is a map and the other is a view list. The presentation of the map uses Google Maps to show the location, while the view list presents information of the people who need help completed with the location and distance. In calculating the maximum route with various geographical location, it assumes that the geographical location as a town and the volunteers as the salesmen on the go [22].

The HelpMe System [23] is Smart Rescue application and system. It uses smartphone technology to assist in the initial crisis times. HelpMe helps map threats and provide help in an emergency situation. Smartphone is used as the input resource to get a picture or the threat, enable and inform people to take action needed to prevent dangers at the site [23]. HelpMe can run many tasks without draining the battery and can still enable smartphone normal use.

First Aid application is developed for Android smartphone; basically the system is a navigation system by using API Google (map) to search for a method and way to the nearest hospital. In any kind of emergency the application can be activated to lead the user to use the shortest route to the nearest hospital [24]. This application gives some useful hints or preventive actions of initial care to patients before sending them to a doctor or hospital. This application also provides a function in searching and finding the closest health clinic or hospital. There are two services provided: a set of first aids guidance and the second is finding an accurate, right and suitable nearby hospital. The first aids service shows how to treat wounds. The second, when in the disaster the patient needs a doctor or to go to a hospital, the application provides a functionality to search and find or lead the way accurately to the closest health clinic or hospital with the use of GPS on the smartphone [24].

Debanjan Das Deb et al. [25] proposed an effective scheme of providing a coordinated post disaster relief operation using smartphone. The smartphone can be used to form peer-to peer wireless network during relief operation to support disaster communication. Mobile nodes communicate with each other in peer to peer mode. At the same time the mobile volunteers also exchange information among one another in a 
peer to peer mode, thus combining field information autonomously and intelligently using auto configurable mobile-phone based peer to peer communication [25].

MyDisasterTraining [26] is a smartphone prototype application which acts as a center for information about disaster training in Malaysia. It involves the government sectors, NGOs, private sectors, and other agencies. It intends to spread the awareness on the availability of disaster training to the social community as well as to invest voluntarily workforce during the need of disaster.

Informer on Site [27] is a mobile application prototype which send information of disaster complaints. The application makes use of a smartphone to take a picture and location of the disaster. The information will automatically sent to the officer in charge to get a rapid response by identifying the location and situation as an early information given by Informer on Site application. This application focuses on natural disasters, such as flood, tornado, fog, and landslide. The application can help the authority to handle the disaster effectively and fast.

Anindito [1], Indriasari [5], and Sigit Purnomo [3] proposed mobile and web application prototype that is useful to collect data of the disaster via mobile or smartphone in Yogyakarta, Indonesia. Later on, the collected data is presented in a web in the form of a map so that it is easy for the relevant institutions to administer the condition in the site and the victims. The research uses SMS-gateway technology and location based service in the implementation.

\section{5 'MyMapVolunteers'}

Based on the analysis stated in sections II, III, and IV, it is necessary to have an application that can detect and map the position of the volunteers in a digital map. Further, the information is used to monitor the distribution ad speed up the coordination of volunteers in order to minimize the number of fallen victims. 'MyMapVolunteers' application is a mobile and web application, the main purpose its application is developing a location based service that can collect the location data of volunteers and present the data in the form of digital map. The knowledge of the volunteers' position in a digital map can be used by the disaster management coordinator to distribute volunteers to certain disaster sites effectively and efficiently. Besides, it enables volunteers to know other volunteers position by using Augmented Reality (AR) feature from 'MyMapVolunteers' application. Marcus Specht et al. [28] "specify augmented reality as a system that enhances a person's primary senses (vision, aural, and tactile) with virtual or naturally invisible information by digital means". The following describes the detail of 'MyMapVolunteers' application.

\subsection{Software Architecture}

'MyMapVolunteers' application is composed of two parts: mobile and web applications. The mobile application will be installed in the volunteers' smartphones (Android smartphone only). Mobile application uses GPS built in the smartphones to get the location coordinates of the smartphone's owner. The location data sending can be 
done in two modes, use manual mode or automatic modes (on the time that has been set). 'MyMapVolunteers' mobile application has searching features, which is searching the mobile application user (volunteers) by employing AR technology. 'MyMapVolunteers' web application is generally used to present the received volunteer location data in the form of google map.

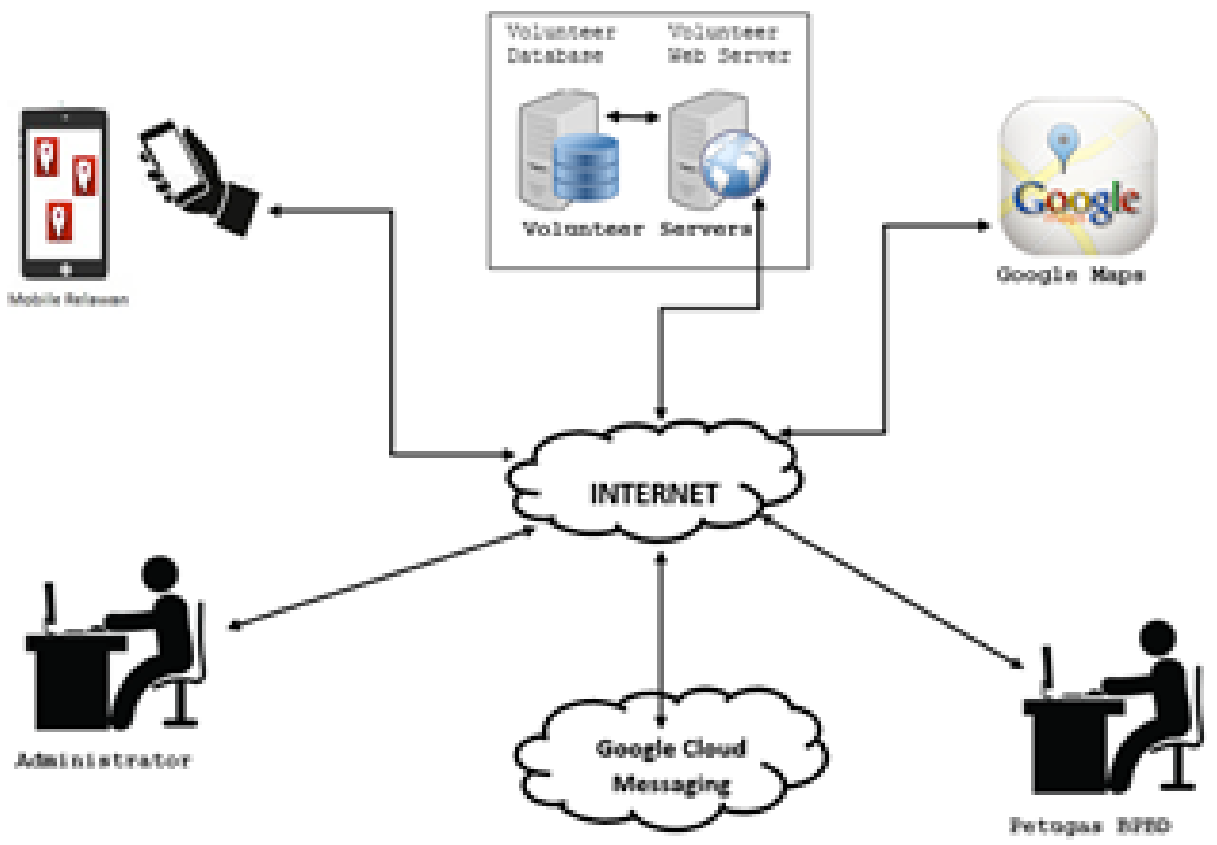

Fig. 2. The Architecture of 'MyMapVolunteers'

Figure 2 illustrates the architecture of 'MyMapVolunteers'. The application has three actors: administrator, BPBD officials (disaster management coordinators), and volunteers. The volunteers can only use the mobile application to update his location manually or automatically in a certain period of time and they can also search for other volunteers by using the Augmented Reality technology. The Augmented Reality feature can search for other volunteers by presenting a marker with the names and distance in between them. BPBD officials and Administrator cannot use mobile application. They can only access the web application. Here, the administrator can manage the profile data of BPBD officials and volunteers. While the BPBD officials can manage volunteers, see the location of volunteers in a digital map and send short messages to volunteers by using Google Cloud Messaging (GCM) service. 


\subsection{Product Features}

'MyMapVolunteers' has some functions that can be clustered into two groups. The first is the functions in the web application and the second in mobile application. The following paragraphs will elaborate the functions.

The Web application can be accessed by two actors, namely administrator and BPBD officials. Administrator can use some functions: login, change password, managing officials, show all volunteers in a digital map, and show the results of filtering the location of volunteers in a digital map. BPBD officials can make use of the functions: login, change password, managing volunteers, show all volunteers location in a digital map, show the results of filtering volunteer locations in a digital map, and send messages to volunteers. 1) Login function is to authenticate user, whether he/she is the authorized user to access the functionality provided by the 'MyMapVolunteers' website. 2) Change password function is to ensure the user's account confidentiality so that it can be modified by the authorized user's only. 3) Official management function is used by the Administrator to add, erase, change, search and reset official's password. 4) Volunteer management function is used by the official to add, erase, change, search and reset volunteer password. 5) Show all volunteer location function will show the location of all volunteers in google maps. 6) Show filtered volunteer location will show the locations of certain volunteers chosen. 7) Send message function is used by official to send broadcast messages to volunteers or to certain volunteers.

Mobile application which can only be accessed by volunteers has the following functions: login, change password, show volunteers positions with AR, navigate location update and show messages. 1) The login function is to ensure the authentication whether the volunteer is legitimate to access the mobile application; 2) Change password function is to change the user's password to ensure the user's safety and comfort; 3) Show volunteer location with AR is to find volunteers around those accessing the function. This access needs a camera in the volunteers' smartphone; 4) Navigation Function shows the route to reach the volunteer needed; 5) Location Update Function is to show the newest location of the volunteer; 6) Message function is to show the sent messages from the administration or official.

The following explains detailed important functions in 'MyMapVolunteers' application. Figure 3 depicts a screenshot of the show all volunteers function. It shows the map of the location of each volunteer with the longitude and latitude coordinates and saved in the database. The location of each volunteer is marked and when the marker is tapped there will be information about the volunteer: name, the SIM card number, the last time the volunteer updated the location, and the longitude and latitude coordinates. The marker is in two colors, red and blue. The red shows that the volunteer is in a normal status. The color automatically changes in within 24 hours if he or she has updated the status. 


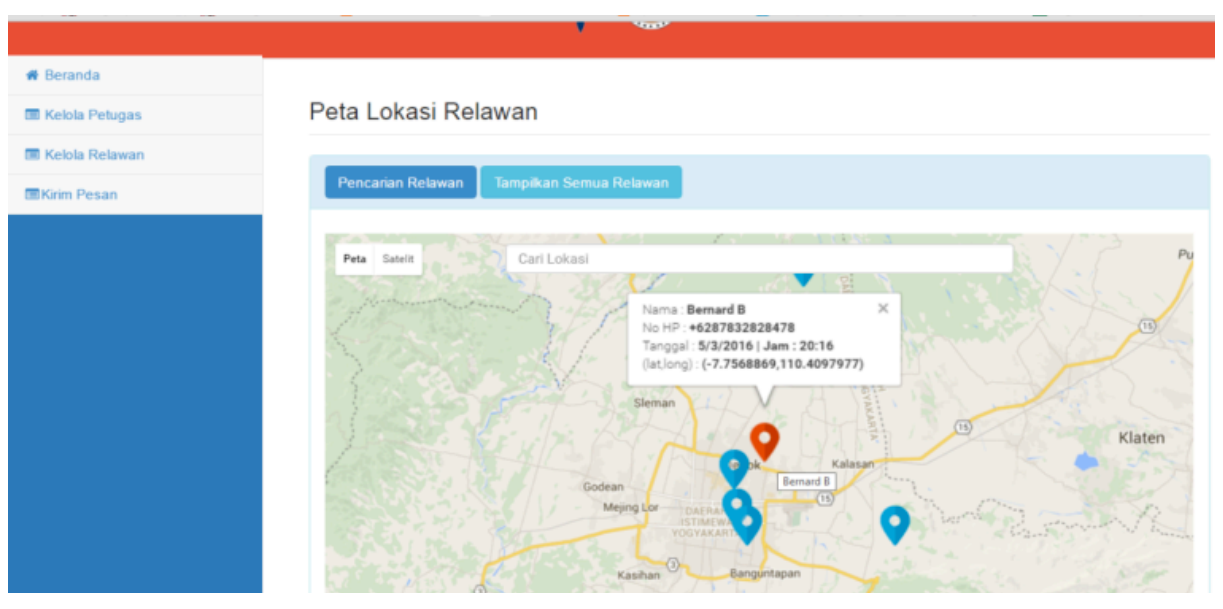

Fig. 3. Mapping Location of Volunteers

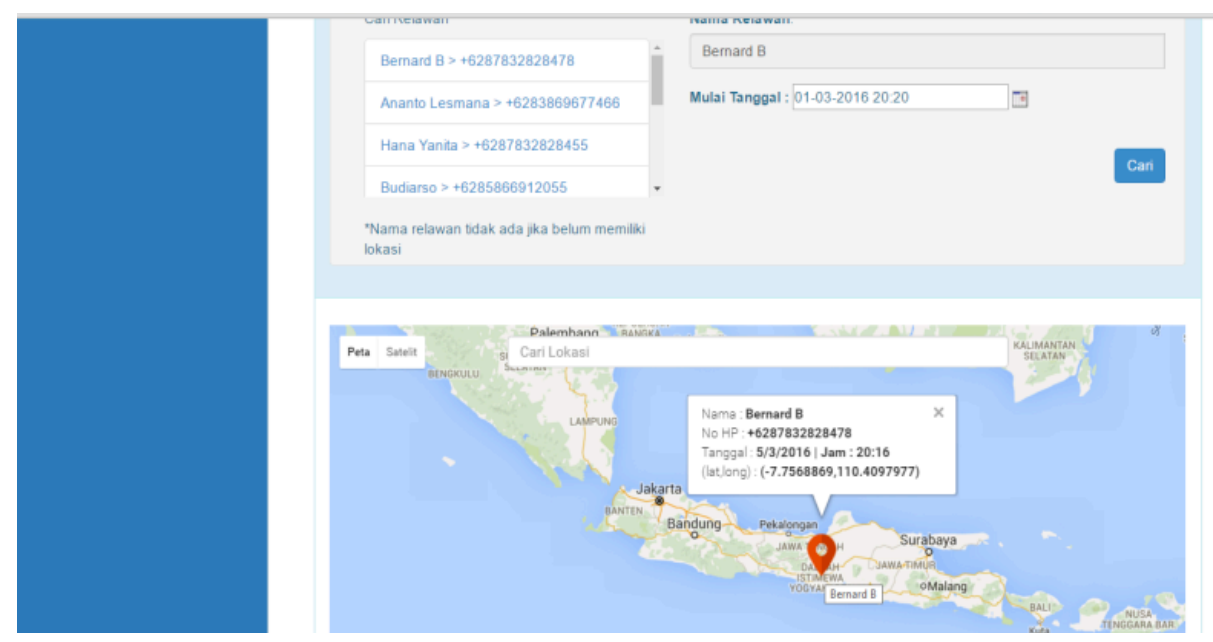

Fig. 4. Filtering the Location of Volunteers

In Figure 3 there is a search for volunteers' button. This button is a filtered show volunteer function. The function interface can be seen in Figure 4. In this function, the users (administrator and operator) can filter volunteers based on name and date of start. The users can filter volunteers based on names only, dates only, or both. The results will show in the map. 


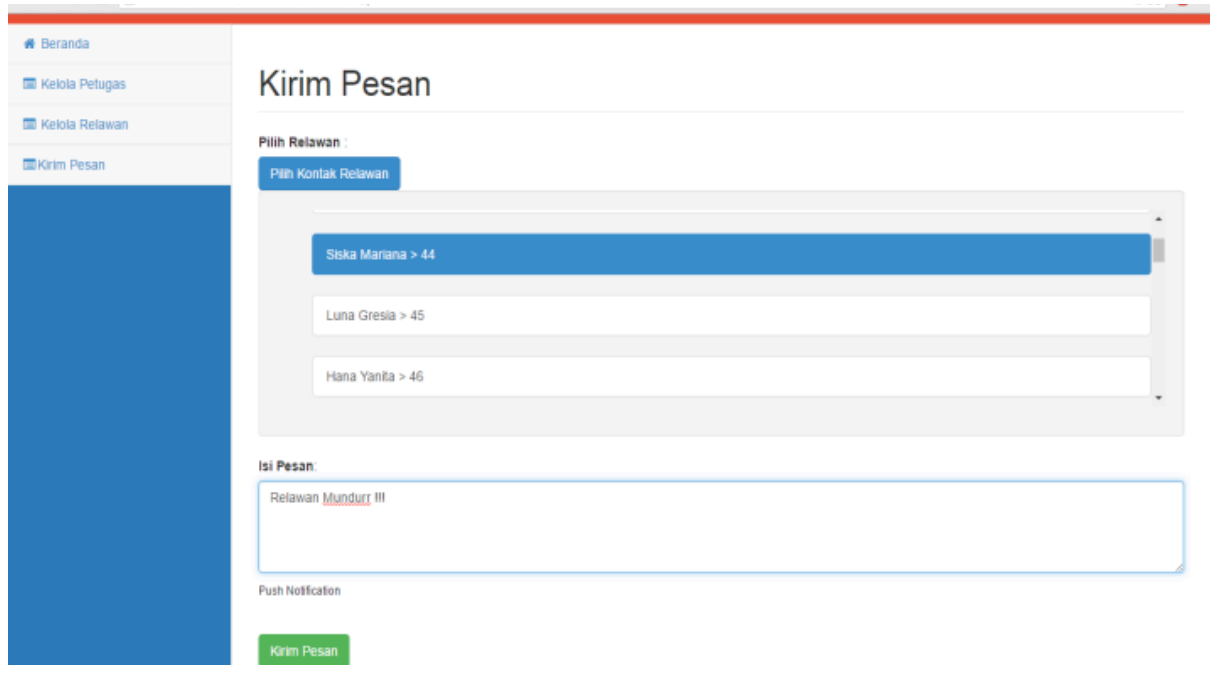

Fig. 5. Sending Message Form

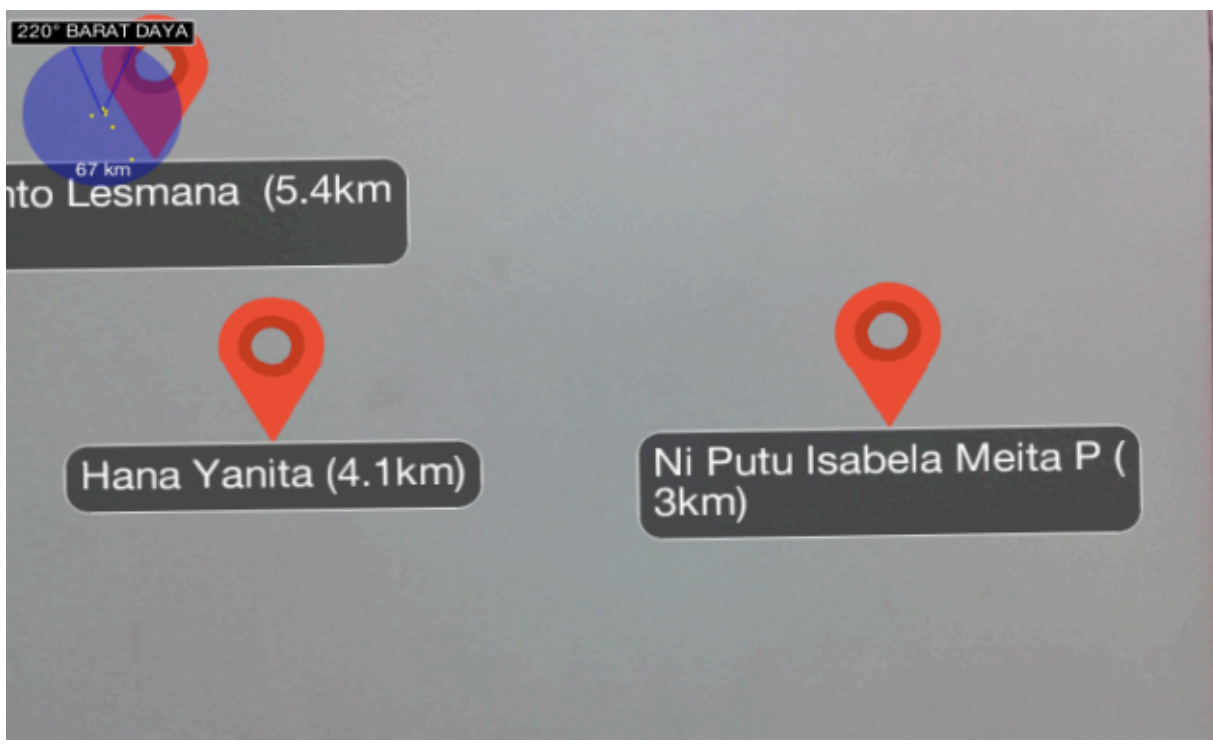

Fig. 6. Location of Volunteers in AR mode

Figure 5 illustrates a form to fill before a message is sent to a volunteer. The operator has two options, 1) broadcast message to all volunteers, or 2) individual message to a certain volunteer of official. The server will send the message to the mobile device belonging to the target volunteers that have logged in to the mobile 'MyMapVolunteers' application. 
Figure 6 is a screenshot of the show volunteer function with the use of AR. This function shows the volunteers' position following the direction of the device movement. A marker will show in 2D form in real time. The marker shows longitude and latitude of the subject based on the information in the database. On each marker, there will be information of the name of volunteers and the distance between volunteers. The maximum distance of this function can reach up to a radius of $75 \mathrm{~km}$ from the access point in the 'MyMapVolunteers' application. This functionality needs a smartphone that has a built-in compass feature.

\section{The Benefits And Drawbacks of 'MyMapVolunteers' Application}

The testing on 'MyMapVolunteers' application is done with black-box method. The result of the test denotes that all features run smoothly. However, it also shows that 'MyMapVolunteers' application has strengths and weaknesses.

The following describes the benefits of 'MyMapVolunteers' application. BPBD officials or disaster management coordinator can: 1) Monitor and search the position of volunteers easily and fast through the show all volunteers and filtering functions; 2) Send fast broadcast messages to all volunteers and important messages to certain volunteers; 3) Detect current situation since 'MyMapVolunteers' mobile application automatically update the recent volunteers positions; 4) Detect which volunteers need extra emergency help in the sites, seen from the red marker of the volunteer mapping.

On the other side, the volunteers also can: 1) Utilize smartphone as a location based service technology to detect his/her position; 1) Easily know the position of other volunteers close to him/her; 2) Reach other volunteers easily by using the navigation function; 3) Receive updated news sent real time by the disaster management coordinators.

The following describes the drawbacks of 'MyMapVolunteers' application: 1) only applicable in Android smartphone; 2) cannot detect the position of volunteers when the battery runs out; 3 ) needs an internet connection minimum $3 \mathrm{G}$ to enable it to use AR feature.

\section{$7 \quad$ Recommendation}

In order for 'MyMapVolunteers' prototype applications can be implemented successfully, it takes a good collaboration between disaster management coordinators and volunteers to conduct field trials or disaster simulation. Training and socialization of the 'MyMapVolunteers' application thoroughly are essential for both parties so that the two platforms can be operated properly. It is also important to consider alternative methods of data transmission between the mobile application and web server when the internet connection (mobile data) fails to work in the field. 


\section{Conclusion}

'MyMapVolunteers' is a mobile application and web application which utilize the GPS function in smartphone to detect the volunteers coordinates and to send the information to a web server. The web application is useful to receive the data of the volunteers' position and present them in the form of a digital map. The local disaster management coordinator (BPBD) can implement this application to map, monitor, search and communicate with the volunteers; therefore the process of disaster management can run smoothly

\section{Acknowledgment}

The authors would like to thank to Indonesian Directorate General of Higher Education who funded this research and Computer Network Laboratory, Informatics Department, Universitas Atma Jaya Yogyakarta that facilitated the authors to conduct the research

\section{References}

[1] K. Anindito, Th. D. Indriasari, E. Julianto, "Konsep Pengembangan Sistem Pengumpulan Data Pengungsi Bencana Alam Berbasis SMS Gateway dan Location-Based Service," in 6th Nat. Digital Information \& Systems Conf. 2014, October 3rd, 2014.

[2] A.M. Julius Sipahutar. (2014, january 2) Tanpa Mitigasi Bencana Indonesia 2014 Masih Menangis [Online]. Available at: http://www.kompasiana.com/musajulius/tanpa-mitigasibencana-indonesia-2014-masih-menangis 5529c6b9f17e613d26d62405

[3] WP, Y. Sigit Purnomo and Indriasari, Theresia Devi and Anindito, Kusworo and Irvan, "A Study of Disaster Situation Management Using Mobile Technology in Yogyakarta," in Proceedings The 2015 International Conference on Data and Software Engineering 2526 Nov. 2016CCIEEE. https://doi.org/10.1109/ICODSE.2015.7436967

[4] Act No. 24/2007. UU nomor 24 tahun 2007 Tentang Penanggulangan Bencana [Online]. Available: http://bnpb.go.id/uploads/migration/pubs/1.pdf

[5] Th. D. Indriasari, K. Anindito, E. Julianto, "Analisis dan Perancangan Sistem Pengumpulan Data Bencana Alam,” Jurnal Buana Informatika. Vol. 6 No. 1 Januari 2015, pp. 73-82. Available: https://ojs.uajy.ac.id/index.php/jbi/article/view/396/444

[6] M. Nasution.(2016, August 10). Peran Serta Relawan Dalam Penanggulangan Bencana [Online]. Available: http://bpbdmadina.info/peran-serta-relawan-dalam-penanggulanganbencana/

[7] I. Fikri. (2010, Nov 8). Relawan merapi, Pengabdian Hingga Akhir Hayat [Online]. Available: $\quad$ http://nasional.inilah.com/read/detail/954732/relawan-merapi-pengabdianhingga-akhir-hayat

[8] B. M. Etsem, B. Walgito, Sugiyanto \& Priyosulistyp. "Sarana Navigasi Kognitif Sebagai Upaya Peningkatan Kemudahan Evakuasi Pada Bangunan Mal/Fasilitas Umum,” Jurnal Psikologi, 35(1), pp. 41-61, 2008.

[9] Lauren S. Fernandez, Joseph A. Barbera, Johan R. van Dorp, "Spontaneous volunteer response to disasters: the benefits and consequences of good intentions". Journal of Emergency Management, Vol. 4, No. 5, September/October 2006, pp 57-68. 
[10] J. Wilson, "Volunteering,” Annu.Rev.Sociol. 26(1)(2000)215-240., p215.

[11] J. Whittaker, B. McLennan, J. Handmer, "A review of informal volunteerism in emergencies and disasters: Definition, opportunities and challenges," International Journal of Disaster Risk Reduction. 13 (2015, pp 358-368)

[12] L. Shaskolsky, "Volunteerism in disaster situations," Preliminary paper no. 1. Disaster Research Center, University of Delaware. Delaware, 1967., p8.

[13] R.P. Wolensky,"Toward abroader conceptualization of volunteerism in disaster," Nonprofit Volunt.Sect.Q.8(1979)33-42, pp35.

[14] Federal Emergency Management Agency (FEMA), Glossary. Available: http://emilms.fema.gov/IS700aNEW/glossary.htm

[15] Badan Nasional Penanggulangan Bencana (BNPB), "Peraturan Kepala Badan Nasional Penanggulangan Bencana Nomor 17 Tahun 2011 Tentang Pedoman Relawan Penanggulangan Bencana," (Decree of the Head of the National Bureau of Disaster Mitigation Number 7 Year 2011). Available: http://bpbd.garutkab.go.id/download/438.\%2017\% 20tahun\%202011\%20(Pedoman\%20Relawan\%20PB\%20).pdf

[16] H. Purnomo and R. Sugianto, "Manajemen Bencana Respons dan Tindakan Bencana," Yogyakarta: Medpress, 2010, 1st ed.

[17] United Nations Development Programme, " Promoting ICT for human development in Asia: Realizing the millennium development goals," India: Elsevier, 2005.

[18] Mike Wills, "Managing the Training Process: putting the basics into practice," Journal of European Industrial Training. vol. 18, pp.4-28, 1994. https://doi.org/10.1108/030905 99410062507

[19] Kerrigan, Karen \& Keating, Raymond J., " Saving time \& Money with mobile applications: a small business 'apps'ortunity,” 2011, available: http://www.sbecouncil.org/ uploads/Mobile\%20APP\%20Final\%20Report\%20SBE\%20Council.pdf

[20] Belisario JS, Marcano, Huckvale K., Greenfield G., Car J., \& Glun LH., "Smartphone \& Tablet self management apps for asthma," (Review), 2013 Nov 27;(11):CD010013. available: https://www.ncbi.nlm.nih.gov/pubmed/24282112 https://doi.org/10.1002/14 651858.CD010013.pub2

[21] Hafsa Maryam, Qaisar javaid, Munam Ali Shah, Muhammad Kamran, "A survey on Smartphone System for Emergency Management (SPSEM)," International Journal of Advanced Computer Science and Application. Vol. 7, No. 6, 2016, pp. 301-311. https://doi.org/10.14569/IJACSA.2016.070639

[22] Jovilyn Therese B. Fajardo, Carlos M. Oppus, "A mobile disaster management system using the android technology," Journal WSEAS TRANSACTIONS on COMMUNICATIONS. Vol. 9 Issue 6, June 2010, pp 343-353.

[23] O. Mokryn, D. Karmi, A. Elkayam and T. Teller, "HelpMe: Opportunistic Smart Rescue Application and System," in The 11th Annual Mediterranean Ad Hoc Networking Workshop (Med-Hoc-Net), 19-22 June 2012, Available: , http://ieeexplore.ieee.org/document/6257129/?reload=true\&arnumber=6257129, $\quad$ DOI: 10.1109/MedHocNet.2012.6257129 https://doi.org/10.1109/MedHocNet.2012.6257129

[24] K. Surachat, S. Kasikri W. Tiprat, and A. Wacharanimit, "First Aid Application on Mobile Device," International Scholarly and Scientific Research \& Innovation. 7(5) 2013,pp-361366.

[25] Debanjan Das Deb, Sagar Bose, and Somprakash Bandyopadhyay, "Coordinating Disaster Relief Operations Using Smart Phone/PDA Based Peer-To-Peer Communication," International Journal of Wireless \& Mobile Networks (IJWMN) . Vol. 4, No. 6, December 2012. 
[26] Nik Nadian Nisa Nik Nazli, Sapora Sipon and Norita Md Norwawi, "One Stop Center For Disaster Training Information In Smartphone Platform: A Mobile Prototype," International Journal of Interactive Mobile Technologies (iJIM) . Vol 9, No 4, 2015 pp 1216. https://doi.org/10.3991/ijim.v9i4.4418

[27] Nik Nadian Nisa Nik Nazli, Sapora Sipon and Norita Md Norwawi, "A Prototype Mobile Application for Informing Disaster Complaint - "Informer on Site, " International Journal of Interactive Mobile Technologies (iJIM). Short Paper. Volume 10, No 1, 2016 pp 68-70.

[28] Specht, M., Ternier, S., \& Greller, W., "Mobile Augmented Reality for Learning: A Case Study,“ Journal Of The Research Center For Educational Technology. 7(1). Retrieved January 18, 2012,available: http://www.rcetj.org/index.php/rcetj/article/view/151

\section{Authors}

Theresia Devi Indriasari, is a lecturer in Informatics Department at Universitas Atma Jaya Yogyakarta, Indonesia. She has more than 13 years of teaching experience. She received her M.Sc. from RWTH University, Germany. Her research interests are mobile computing, social network analysis, human computer interaction, Internet of Things, and disaster management.

Kusworo Anindito is a lecturer in Informatics Department at Universitas Atma Jaya Yogyakarta, Indonesia. He has more than 15 years of teaching experience. He received his Master of Engineering from Institut Teknologi Bandung, Indonesia. His research interest are mobile and web application, computer network, and disaster management

Eddy Julianto is a lecturer in Informatics Department at Universitas Atma Jaya Yogyakarta, Indonesia. He has more than 15 years of teaching experience. He received his Master of Engineering from Universitas Gadjah Mada, Indonesia. His research interests are mobile computing, microcontroller, and Internet of Things.

Bertha Pangaribuan was student in Informatics Department at Universitas Atma Jaya Yogyakarta. She has more than two years of experience as assistant lecturer at Universitas Atma Jaya Yogyakarta. She received her bachelor degree in 2016. Now, she works as Associate Consultant Oracle.

Article submitted 30 November 2016. Published as resubmitted by the authors 23 January 2017. 